\title{
Dexamethasone potentiates the antiangiogenic activity of docetaxel in castration-resistant prostate cancer
}

\author{
C Wilson ${ }^{1,4}$, P Scullin',4, J Worthington ${ }^{2}$, A Seaton', P Maxwell', D O'Rourke ${ }^{3}$, PG Johnston', SR McKeown², \\ RH Wilson', JM O'Sullivan' and DJJ Waugh*,I
}

'Centre for Cancer Research and Cell Biology, Queen's University Belfast, Belfast BT9 7BL, Northern Ireland; '2School of Biomedical Sciences, University of Ulster, Coleraine BT52 ISA, Northern Ireland; ${ }^{3}$ Department of Histopathology, Belfast City Hospital, Belfast BT9 7AB, Northern Ireland

We sought to characterise whether dexamethasone (DEX) may enhance tumour response to docetaxel in in vitro and in vivo models of metastatic prostate cancer (CaP). In vitro experiments conducted on PC3 and human bone marrow endothelial cells (hBMECs) determined that administration of DEX (I $0 \mathrm{nM}$ ) reduced constitutive nuclear factor- $\kappa \mathrm{B}(\mathrm{NF}-\kappa \mathrm{B})$ activity, decreasing interleukin (IL)-8, CXCLI and VEGF gene expression in PC3 cells. Dexamethasone also attenuated docetaxel-induced NF- $\kappa$ B and activator protein- 1 transcription and reduced docetaxel-promoted expression/secretion of IL-8 and CXCLI in PC3 and hBMECs. Although DEX failed to enhance docetaxel cytotoxicity on PC3 cells, DEX potentiated the antiangiogenic activity of docetaxel in vitro, further reducing vessel area and vessel length in developing endothelial tubes $(P<0.05)$. Docetaxel had a potent antiangiogenic activity in the dorsal skin flap-implanted PC3 tumours in vivo. Small blood vessel formation was further suppressed in tumours co-treated with docetaxel and DEX, substantiated by an increased average vessel diameter and segment length and a decreased number of branch points in the residual tumour vasculature $(P<0.00 \mathrm{I})$. Our data show that DEX potentiates the antiangiogenic activity of docetaxel, suggesting a putative mechanism for the palliative and survival benefits of these agents in metastatic CaP.

British Journal of Cancer (2008) 99, 2054-2064. doi:I0.1038/sj.bjc.6604804 www.bjcancer.com

Published online 2 December 2008

(c) 2008 Cancer Research UK

Keywords: dexamethasone; docetaxel; angiogenesis; prostate cancer

Prostate cancer $(\mathrm{CaP})$ is now the second most common cause of male cancer death in the Western society. Castration therapy (either surgical orchidectomy or luteinizing hormone releasing hormone agonists) is initially effective in treating recurrent or metastatic CaP. However, the majority of these patients will become refractory to castration as the cancer loses dependence on androgen-signalling. As a further complication, castration-resistant $\mathrm{CaP}$ (CRPC) is poorly sensitive to conventional cytotoxic chemotherapy. However, two recent phase III trials, the TAX 327 and SWOG 9916 trials, have reported a survival benefit together with superior pain response, PSA response rate and improvement in quality of life in patients with hormone refractory, metastatic $\mathrm{CaP}$ receiving docetaxel (Taxotere ${ }^{-}$) as opposed to mitoxantrone therapy. Accordingly, docetaxel has become the chemotherapy of choice for men with metastatic CRPC (Petrylak et al, 2004; Tannock et al, 2004).

Glucocorticoids, such as dexamethasone (DEX), have also been shown to exhibit single-agent activity in CRPC. Low dose, daily DEX administration has been reported to yield biochemical PSA response rates of up to $49 \%$ in CRPC (Venkitaraman et al, 2008). The

*Correspondence: Dr DJJ Waugh, Centre for Cancer Research and Cell Biology, Queen's University Belfast, 97 Lisburn Road, Belfast BT9 7BL, Northern Ireland; E-mail: d.waugh@qub.ac.uk

${ }^{4}$ These authors contributed equally to this work.

Received I October 2008; revised 5 November 2008; accepted 5 November 2008; published online 2 December 2008 mechanism by which glucocorticoids exert their effect in cancer is not well elucidated, although several mechanisms have been postulated. Glucocorticoids have been shown to interfere with the transcriptional activity of nuclear factor $-\kappa \mathrm{B}(\mathrm{NF}-\kappa \mathrm{B})$ and activator protein-1 (AP-1) (Nishimura et al, 2001), resulting in the suppression of the interleukin-6 (IL-6) and the NF- $\kappa$ B-IL-6 pathways in CaP (Akakura et al, 2003; De Bosscher et al, 2003). Dexamethasone has also been shown to inhibit angiogenesis in a $\mathrm{CaP}$ xenograft model, reducing cell and tumour IL-8 and VEGF expression in in vitro and in vivo assays, respectively (Yano et al, 2006).

CXC-chemokines including IL-8 have an established role in promoting the progression of CaP (Waugh et al, 2008). Interleukin-8 expression has been shown to be elevated in $\mathrm{CaP}$ tissue by immunohistochemistry (Huang et al, 2005; Murphy et al, 2005) and by in situ hybridisation (Uehara et al, 2005), whereas overexpression of IL-8 has been detected in the serum of $\mathrm{CaP}$ patients (Veltri et al, 1999; McCarron et al, 2002). Furthermore, IL-8 expression in CaP tissue has been associated with increased biochemical recurrence (Caruso et al, 2008). Consistent with this, studies in athymic mice have correlated the increased expression of IL-8 in implanted human CaP cells with increased vascularisation of the tumours and an enhanced tumourigenic and metastatic potential (Inoue et al, 2000; Kim et al, 2001). Other studies have determined the relevance of IL-8 signalling to the development of androgen-independence (Araki et al, 2007; Seaton et al, 2008), CaP cell proliferation (Murphy et al, 2005) and CaP cell survival in response to environmental and chemotherapy/biological agents (Maxwell et al, 2007; Wilson et al, 2008a, b). 
Glucocorticoids are frequently provided to patients to offset fluid retention and hypersensitivity responses to taxane administration and were present as an element of the TAX327 and SWOG9916 trial regimens. Furthermore, given that DEX exhibits single-agent activity in this disease (Venkitaraman et al, 2008), we established this pre-clinical study to determine whether two agents used clinically and often together during therapy may act to enhance the activity of the other in experimental models of CRPC. Therefore, our experiments focused on elucidating the effect of DEX and docetaxel in modulating CXC-chemokine expression and signalling within CRPC cells, with the intent of characterising a mechanism to explain how DEX might enhance docetaxel response in this disease.

\section{MATERIALS AND METHODS}

\section{Chemical and reagents}

Chemicals were purchased from Sigma Chemical Co. (St Louis, MO, USA) unless otherwise stated.

\section{Cell culture}

Human PC3 and LNCaP cells were sourced and grown in RPMI 1640 medium supplemented with $10 \%$ fetal bovine serum and $4 \mathrm{~mm}$ L-glutamine (Invitrogen Ltd, Paisley, UK) as previously described (Maxwell et al, 2007; Wilson et al, 2008a). The hBMEC line was kindly provided by Dr Babette B Weksler of Weill Medical College, Cornell University, New York. Human BMECs were maintained in DMEM medium supplemented with 5\% FCS, 3\% L-glutamine and HEPES (10 mM). All cultures were maintained in a humidified chamber at $37^{\circ} \mathrm{C}$ with $5 \% \mathrm{CO}_{2}$.

\section{Cell count analysis}

Cells were seeded into 24 -well plates $\left(1 \times 10^{5}\right.$ cells per well $)$ in RPMI 1640 medium and allowed to attach overnight. Cells were then treated with DEX $(10 \mathrm{nM})$. Plates were incubated in a humidified chamber at $37^{\circ} \mathrm{C}$ with $5 \% \mathrm{CO}_{2}$ for 24,48 or $72 \mathrm{~h}$, and the cells were trypsinised and counted in triplicate using a Coulter $\mathrm{Z}$ series particle count and size analyzer (Beckman Coulter, High Wycombe, UK). Cell numbers were normalised to control values.

\section{Quantitative real-time PCR (QPCR)}

Total RNA was isolated using RNAStat60 (Biogenesis, Oxford, UK) according to the manufacturer's instructions. For real-time PCR, $10 \mu \mathrm{g}$ of total RNA was oligo(dT) reverse transcribed using MMLVRT (Invitrogen) according to the manufacturer's instructions. The cDNA (100 ng) was mixed with primers $(2 \mu \mathrm{M})$, sterile water and SYBR Green PCR mastermix (Finnzymes, Espoo, Finland). The primer sequences were as follows: $18 \mathrm{~S}$ : forward, $5^{\prime}$-CAT TCg TAT TGC GCC gCT- $3^{\prime}$; reverse, $5^{\prime}$ - CGA Cgg TAT CTg ATC gTC-3'; IL-8; forward, 5'-ATg ACT TCC AAg CTg gCC gTg g; reverse, 5' - CAT AAT TTC TGT GTT ggC gCA gTg Tgg; CXCL1: forward, CCC AAg AAC ATC CAA AgT gTC A; reverse, gTg gCT ATg ACT TCg gTT Tg; VEGF: forward, 5' - AgC TAC TgC CAT CCA ATC gA; reverse, $5^{\prime}$ - ggT gAg gTT TgA TCC gCA TA. Real-time PCR was carried out in a 96-well plate using an Opticon 2 Continuous Fluorescence Detector (Biorad, Hertfordshire, UK). Amplification was $95^{\circ} \mathrm{C}$ for $15 \mathrm{~min}$, and $45 \mathrm{cycles}$ at $95^{\circ} \mathrm{C}$ for $15 \mathrm{~s}, 55^{\circ} \mathrm{C}$ for $30 \mathrm{~s}$ and $72^{\circ} \mathrm{C}$ for $60 \mathrm{~s}$. The threshold cycle $\left(C_{\mathrm{t}}\right)$, which indicates the relative abundance of a particular transcript, was calculated for each reaction by the Opticon 2 system. Expression levels were determined from standard curve dilutions and normalised for $18 \mathrm{~s}$.

\section{Transfection and luciferase assay}

Cells were plated in six-well plates $\left(1 \times 10^{5}\right.$ cells per well $)$ in RPMI 1640 medium and incubated for $48 \mathrm{~h}$ at $37^{\circ} \mathrm{C}$ with $5 \% \mathrm{CO}_{2}$. Cells were transfected using GeneJuice transfection reagent (Merck Chemicals. Nottingham, UK), according to manufacturer's protocol, with $2 \mu \mathrm{g}$ pGL3 basic vector (Promega, Madison, WI, USA) or $2 \mu \mathrm{g}$ of an NF- $\kappa \mathrm{B}-\mathrm{LUC}$ plasmid (kindly provided by Dr James Purcell, QUB) or $0.5 \mu \mathrm{g}$ of an AP-1-LUC plasmid (kindly provided by Dr Massimo Gadina, QUB). Cells were also co-transfected with $0.2 \mu \mathrm{g}$ of a Renilla luciferase plasmid as a transfection control for pGL3 and NF- $\kappa \mathrm{B}$ or $0.01 \mu \mathrm{g}$ of a Renilla luciferase plasmid as a transfection control for AP-1. Cells were incubated for $24 \mathrm{~h}$ before drug addition. The drug of interest was added for the desired time and the samples were analysed by luciferase assay using the Promega Dual Luciferase assay kit (Promega) according to the manufacturer's protocol.

\section{Enzyme-linked immunosorbent assay (ELISA)}

Cells were plated in 24-well plates $\left(5 \times 10^{4}\right.$ cells per well) in RPMI 1640 medium. Following an overnight incubation, the medium was replaced with fresh media, docetaxel (1 nM) or DEX (10 nM), or a combination of both drugs were added to cells for the indicated time. A time-matched control with no drug was also included. The supernatant was removed from the cells and centrifuged at $1000 \mathrm{~g}$ for $5 \mathrm{~min}$ to remove any cell debris and the supernatant was stored at $-20^{\circ} \mathrm{C}$ until assayed. The cell number in each well was determined by parallel cell count analysis. CXCL8 levels were measured using the Pelikine Compact $^{\mathrm{TM}}$ IL-8 ELISA Kit (Sanquin Reagents, Amsterdam, The Netherlands), whereas CXCL1 levels were determined using the Quantikine ${ }^{\mathrm{R}}$ kit (R\&D Systems, Abingdon, UK). The manufacturer's instructions were used in the application of each ELISA kit. Absorbance readings were taken at $450 \mathrm{~nm}$ using a microwell plate reader (Molecular Devices, Wokingham, UK).

\section{3-(4,5-dimethylthiazol-2-yl)-2,5-diphenyltetrazolium bromide (MTT) assay}

Cells were seeded into 96-well plates $\left(3 \times 10^{3}\right.$ cells per well $)$ in RPMI 1640 medium and allowed to attach overnight. Serial dilutions of docetaxel (kind gift from Belfast City Hospital Pharmacy) or DEX were added to the cells alone and, in the case of docetaxel, in combination with a fixed concentration of DEX $(10 \mathrm{nM})$. In other experiments, cells were treated with $5 \mu \mathrm{M}$ BAY-117082 (Calbiochem, La Jolla, CA, USA), a monoclonal neutralising antibody for IL-8, at a final concentration of $4 \mu \mathrm{g} \mathrm{ml}^{-1}$ (R\&D Systems, Abingdon, UK) or a selective CXCR2 receptor antagonist AZ10397767 (Walters et al, 2008) (kindly provided by Dr Simon T. Barry, AstraZeneca, Alderley Park, UK). Plates were incubated in a humidified chamber at $37^{\circ} \mathrm{C}$ with $5 \% \mathrm{CO}_{2}$ for $72 \mathrm{~h}$, then $50 \mu$ l MTT $\left(2 \mathrm{mg} \mathrm{ml}^{-1}\right)$ was added and the plates returned to the incubator for $4 \mathrm{~h}$. Medium and any unmetabolised MTT was aspirated from the wells and the formazan crystals were dissolved in $100 \mu \mathrm{l}$ dimethyl sulphoxide. Absorbance was read at $570 \mathrm{~nm}$ using a microplate reader (Molecular Devices).

\section{Angiogenesis assay}

AngioKit (GB patent 2331763) consisting of one 24-well pre-seeded tissue culture plate containing early stage co-cultures of human endothelial cells and other human cells, five $25 \mathrm{ml}$ single use bottles of optimised media, positive (VEGF) and negative (suramin) controls and CD31 (PECAM-1) staining kit was supplied by TCS CellWorks Ltd (Buckingham, UK). Fresh media, media with positive control (VEGF), media with suramin or media plus docetaxel (1 nM), DEX (10 nM) or a combination of both was added to each well on days $1,4,7$ and 9 as per the manufacturer's 
instructions. Cells were treated with each test compound in triplicate. Plates were incubated in a humidified chamber at $37^{\circ} \mathrm{C}$ with $5 \% \mathrm{CO}_{2}$ for 11 days, then fixed and stained with anti-CD31 according to the manufacturer's instructions. Images were analysed using a LEICA DMLB microscope and LUICA measurement software (Leica Microsystems (UK) Ltd, Milton Keynes, UK). For each well, 15 fields were analysed using the five-times objective. The length and area of each vessel were measured using the LUICA measurement software. Mean vessel length and area, as well as total vessel length and area in 15 fields in each of the triplicate wells were calculated (Microsoft Excel software).

\section{Dorsal skin flap model}

Imaging of the tumour vasculature in an implanted PC3 tumour was conducted in 12-week-old male BALB-c SCID mice as previously described (O'Rourke et al, 2008). Briefly, a viewing chamber was attached to a raised skin flap on the dorsal flank of the mouse under anaesthesia and a fragment $(0.5 \mathrm{~mm})$ of PC3 prostate tumour (excised from a donor mouse) was placed on the exposed microvascular bed. The PC3 tumour vasculature was imaged 7 days postsurgery, (tumours measured $2 \mathrm{~mm}$ in diameter), by injection of $50 \mu \mathrm{l}$ of $150 \mathrm{kDa}$ FITC-labeled dextran $\left(50 \mathrm{mg} \mathrm{ml}^{-1}\right)$ into the tail vein under light anaesthesia. The viewing chamber was illuminated with a mercury lamp, and the FITC signal was detected with an ORCA-ER camera system (Hamamatsu Photonics, Welwyn Garden City, UK). Images were recorded using Image J software (NIH, Bethesda, MD, USA). Mice then received DEX (10 nM), docetaxel $(0.5 \mathrm{nM})$ or a combination of DEX $(10 \mathrm{nM}) /$ docetaxel $(0.5 \mathrm{nM})$, administered directly to the sealed chamber on days 8,11 and 14 post-implantation. Control animals received injections of PBS at similar time points. Imaging was repeated at days 9, 11, 15 and 18 post-implantation. Experiments were carried out in accordance with the Animal (Scientific Procedures) Act 1986 and conformed to the current United Kingdom Coordinating Committee on Cancer Research guidelines.

\section{Statistical analysis}

Two-tailed Student's $t$-tests were performed using GraphPad Prism 4.0 software to compare mean values in drug-treated $\mathrm{CaP}$ and endothelial cells for each of the following in vitro experiments: analysis of gene expression and secretion, comparison of cell viability and determination of vessel formation in the AngioKit assay. Statistical analysis of the tumour vascular parameters in the dorsal skin flap model was performed using a one-way ANOVA (Microsoft Excel software).

\section{RESULTS}

\section{Effect of DEX on basal NF- $\kappa$ B activity in PC3 cells}

Constitutive activation of the NF- $\kappa \mathrm{B}$ transcription factor has been reported in $\mathrm{CaP}$ and is associated with disease progression, chemoresistance, angiogenesis and metastasis (Huang et al, 2001; Fradet et al, 2004; Ross et al, 2004; Shukla et al, 2004; Sweeney et al, 2004; Domingo-Domenech et al, 2005). Nuclear factor- $\kappa \mathrm{B}$ has been reported to induce the transcription of proinflammatory genes, many of which have been implicated in each of the above phenotypes. Given the anti-inflammatory activity of glucocorticoids, we initially determined the effect of DEX administration upon the constitutive transcriptional activity of NF- $\kappa \mathrm{B}$ in PC3 cells. The PC3 cells were transfected with the pGL3-NF- $\kappa$ B luciferase construct. Addition of DEX (10 nM) was shown to effect a sustained repression of NF- $\kappa \mathrm{B}$-luciferase activity in transfected PC3 cells. The maximal inhibition of NF- $\kappa \mathrm{B}$ activity was observed $6 \mathrm{~h}$ postadministration of DEX, attenuating NF- $\kappa$ B activity to $39 \%$ of that in control cells $(P<0.05)$ (Figure 1A).

\section{DEX downregulates IL-8 and VEGF expression in PC3 cells}

Having shown that DEX downregulates NF- $\kappa \mathrm{B}$ activity, we confirmed whether DEX modulated the expression of the proangiogenic NF- $\kappa \mathrm{B}$ transcriptional target, IL-8. Using QPCR, we observed a time-dependent decrease in IL-8 transcript levels in PC3 cells following a single administration of DEX (10 nM), suppressing the constitutive IL-8 mRNA transcript expression in PC 3 cells to $38 \%$ of that in untreated cells $48 \mathrm{~h}$ post-treatment with DEX $(P<0.01)$ (Figure 1B). Similarly, administration of DEX was also shown to reduce the expression of the related proangiogenic CXC-chemokine, CXCL1 $(P<0.05$ at the $48 \mathrm{~h}$ time point). In a further analysis, we determined the effect of DEX on the gene expression of VEGF, another angiogenesis-promoting factor whose transcription is also regulated by NF- $\kappa$ B activity. The VEGF mRNA transcript levels also showed a time-dependent decrease following administration of DEX (10 nM) to PC3 cells that was evident within $6 \mathrm{~h}$ and was maximal (45\%) by $24 \mathrm{~h}$ (Figure $1 \mathrm{~B}$ ).

To confirm that the observed downregulation of IL- 8 mRNA transcript levels in PC3 cells corresponded with a decreased rate of IL-8 secretion, we performed an ELISA. The PC3 cells were treated with a single dose of DEX $(10 \mathrm{nM})$, and media samples were collected between 6 and $72 \mathrm{~h}$ post-administration of the glucocorticoid. To account for any time-dependent accumulation of secreted IL-8 in cultured PC3 cells, we collected a time-matched control sample alongside each treated sample. The secretion of IL-8 was normalised relative to cell number and expressed as a percentage of the time-matched, untreated sample. Administration of DEX (10 nM) effected a time-dependent suppression of IL-8 secretion from PC3 cells, reaching a maximal inhibition at $24 \mathrm{~h}$ $(P<0.05)$. However, the level of IL-8 secretion recovered to baseline levels $72 \mathrm{~h}$ post-treatment (Figure 1C). Similarly, experiments with DEX effected a similar reduction in basal IL-8 secretion from androgen-dependent $\mathrm{CaP}$ cells (LNCaP), reducing the secretion to $75 \%$ of basal levels $24 \mathrm{~h}$ after addition of DEX $(P<0.05)$ (data not shown). As in the clinical setting, DEX is administered daily, we also determined the effect of daily DEX (10 nM) on IL-8 and CXCL1 secretion in PC3 cells; this prevented the return to basal levels of IL-8 secretion and also resulted in a sustained, although smaller, decrease in CXCL1 secretion (Figure 1D).

\section{Effect of DEX on PC3 and endothelial cell proliferation}

Experiments were established to determine the effect of DEX on PC3 cell proliferation. The PC3 cells were treated with DEX over a concentration range of $0.1 \mathrm{nM}$ to $10 \mu \mathrm{M}$ for $72 \mathrm{~h}$ and an MTT assay performed to assess cell viability. Dexamethasone had no inhibitory effect on PC3 cell proliferation at any concentration studied over this $72 \mathrm{~h}$ period (data not shown). The effect of DEX on PC3 cell growth over a time course was also examined. Cell count analysis was performed at 24,48 and $72 \mathrm{~h}$ after addition of $10 \mathrm{~nm}$ DEX to PC3 cells. Relative to unstimulated cells, administration of $10 \mathrm{~nm}$ DEX was observed to have no significant effect on cell proliferation (data not shown). Dexamethasone $(0-1 \mu \mathrm{M})$ also had no inhibitory effect on LNCaP or hBMEC cell proliferation (data not shown).

\section{DEX attenuates docetaxel-induced NF- $\kappa \mathrm{B}$ and AP-1 activity in PC3 cells}

Patients with CRPC frequently receive DEX in combination with docetaxel. Using the aforementioned luciferase reporter assays, we studied the impact of administering DEX and docetaxel in combination upon NF- $\kappa \mathrm{B}$ and $\mathrm{AP}-1$ transcriptional activity in PC3 cells. Measurements of transcription factor activity were conducted $24 \mathrm{~h}$ post-administration of the drug treatments. The PC3 cells were treated with a single dose of docetaxel (1 nM), alone 

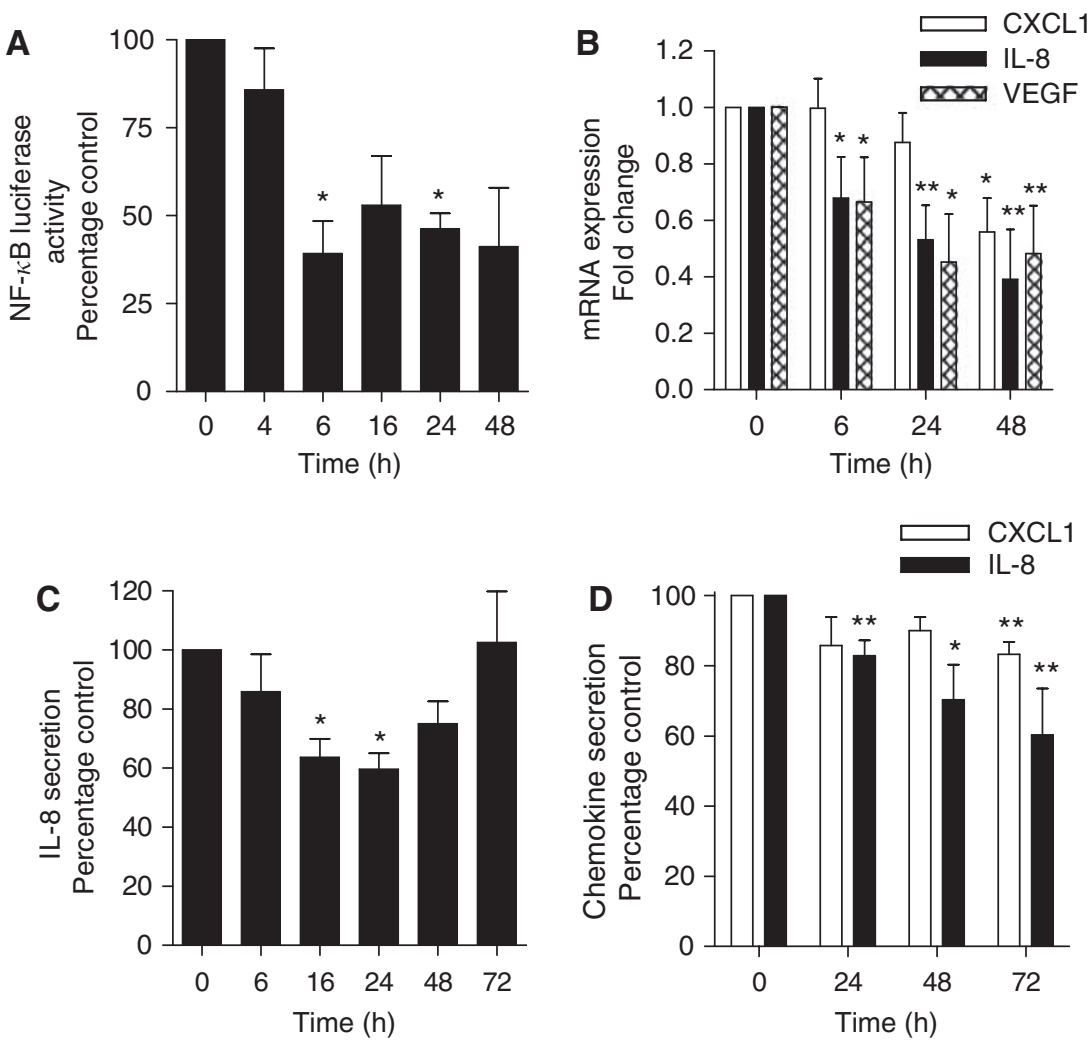

Figure I Dexamethasone (DEX) decreases expression and secretion of proangiogenic CXC-chemokines in PC3 cells. (A) Bar graph illustrating the effect of $10 \mathrm{nM}$ DEX on NF- $\kappa$ B-driven transcriptional activity in PC3 cells transfected with a pGL3-NF- $\kappa$ B-LUC plasmid compared with time-matched controls transfected with an empty vector and normalised against Renilla luciferase activity as described in Materials and Methods. Data shown are the mean \pm s.e.m. of six independent experiments. (B) Bar graph illustrating the relative mRNA transcript levels for the proangiogenic factors IL-8, CXCLI and VEGF in PC3 cells, determined by QPCR over a $48 \mathrm{~h}$ time course post-treatment with $10 \mathrm{nM}$ DEX. Values shown represent the mean \pm s.e.m. value, determined from three or four independent experiments. (C) Bar graph illustrating the relative secretion of the CXC-chemokine IL-8 from PC3 cells following treatment with a single administration of $10 \mathrm{nM}$ DEX. The concentration of IL-8 secreted into the culture media was determined by ELISA. Data shown are the mean \pm s.e.m. value of six independent experiments. (D) As in $(\mathbf{C})$, except that $10 \mathrm{~nm}$ DEX was administered to the PC3 cells every $24 \mathrm{~h}$. Data shown are the mean \pm s.e.m. value of four independent experiments. Statistically significant differences in activity, transcript levels or secretion were determined using a two-tailed Student's $t$-test analysis. $* P<0.05 ; * * P<0.0$ I.

or co-administered with DEX (10 nM). Docetaxel doubled NF- $\kappa$ B activity in the PC3 cells compared with control unstimulated cells $(P<0.05)$; however, this was reduced to basal levels in the presence of DEX $(P<0.05$ relative to docetaxel alone) (Figure $2 \mathrm{~A})$. Similarly, docetaxel administration increased AP-1 transcriptional activity in PC3 cells by over two-fold $(P<0.01)$. Co-administration of DEX attenuated but did not abrogate the docetaxel-induced AP-1 activity in these PC3 cells $(P<0.01)$ (Figure $2 \mathrm{~B})$.

Having shown that DEX attenuated docetaxel-induced potentiation of NF- $\kappa$ B and AP-1 transcriptional activity, we confirmed the effect of administering these drugs alone or in combination upon the regulation of the IL- 8 and CXCL1 genes. The PC3 cells were treated with docetaxel $(1 \mathrm{nM})$ alone, or concurrently with DEX $(10 \mathrm{nM})$. The mRNA samples were harvested from the cells $24 \mathrm{~h}$ post-treatment. The mRNA transcript levels for IL-8 and CXCL1 were then quantified relative to that of the housekeeping gene $18 \mathrm{~S}$ using the established, gene-specific QPCR assays. Docetaxel administration resulted in increasing IL-8 mRNA and CXCL1 mRNA transcript levels to over 1.5 -fold of that detected in timematched, untreated cell populations (Figure 2C); this was attenuated by the concurrent administration of DEX $(P<0.05$ in both cases).

We also used an ELISA to determine the impact of docetaxel on IL-8 and CXCL1 secretion from PC3 cells. All values for CXCchemokine secretion were normalised against cell number and expressed as a percentage of that measured in time-matched, untreated samples. In initial experiments, we conducted a time course to determine how docetaxel influenced the rate and magnitude of IL-8 secretion from PC3 cells. Docetaxel potentiated IL-8 secretion in a time-dependent manner, increasing the extracellular level of this chemokine to 175 and $160 \%$ of that determined in untreated, time-matched controls, 16 and $24 \mathrm{~h}$ postaddition of this taxane, respectively $(P<0.05)$ (data not shown). In further experiments, the level of IL-8 in the cell media was quantified and normalised $24 \mathrm{~h}$ post-administration of docetaxel, in the absence and presence of DEX (10 nM). Docetaxel induced IL- 8 secretion to $168 \%$ of that detected in untreated PC3 cells $(P<0.001)$. However, concurrent treatment with DEX attenuated the docetaxel-induced increase in IL- 8 secretion, reducing IL- 8 secretion to approximately $10 \%$ below that observed in untreated cells $(P<0.001)$ (Figure $2 \mathrm{D})$. A similar trend was determined for the effect of these drugs in promoting CXCL1 secretion from PC3 cells. Again, DEX was shown to reverse docetaxel-induced CXCL1 secretion $(P<0.05)$ (Figure 2D).

\section{DEX attenuates docetaxel-induced IL-8 expression and secretion in endothelial cells}

Further experiments were conducted on hBMECs to determine the effects of DEX, docetaxel and a combination of DEX with docetaxel on IL-8 and CXCL1 gene transcription and the secretion of these CXC-chemokines by endothelial rather than tumour cells. 

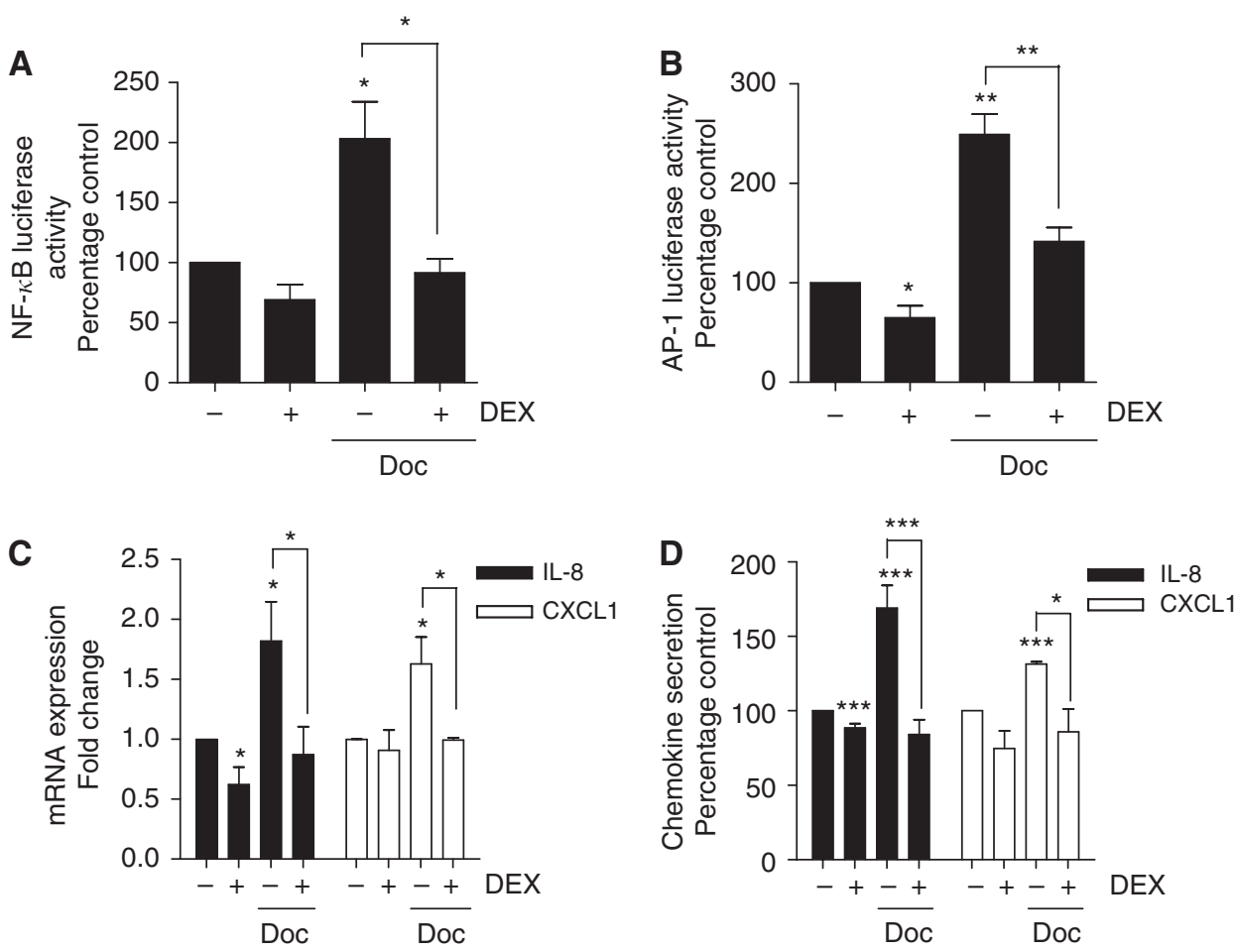

E BMEC

$\mathbf{F}$ BMEC
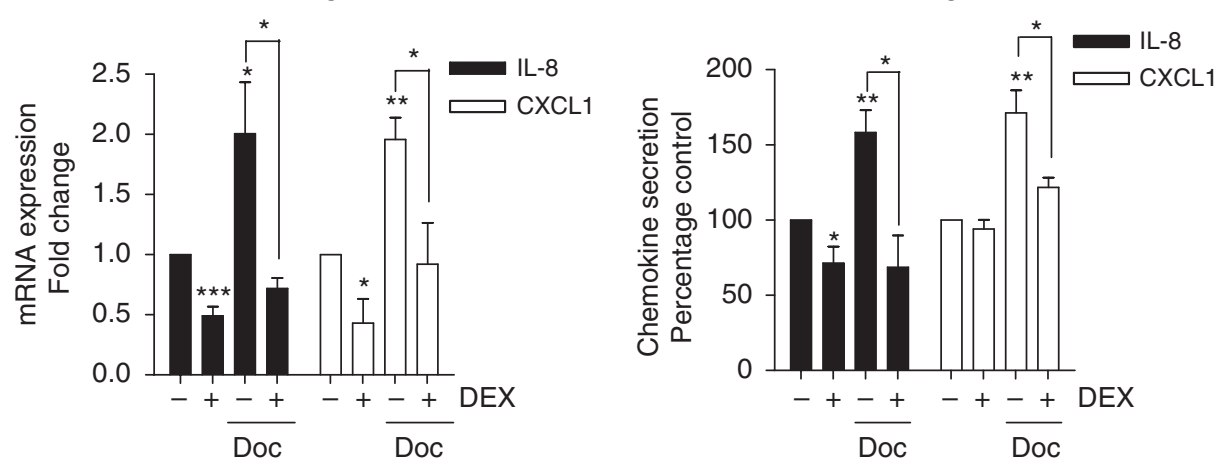

Figure 2 Effect of dexamethasone (DEX) upon docetaxel-induced transcriptional regulation and potentiation of CXC-chemokine expression/secretion by PC3 and endothelial cells. (A) Bar graph illustrating the effect of I nM docetaxel (Doc) or I 0 nM DEX, singly or in combination, upon NF- $\kappa$ B-driven transcriptional activity in PC3 cells transfected with a PGL3-NF- $\kappa$ B-LUC plasmid measured $24 \mathrm{~h}$ post-addition of the drugs. This is compared with timematched controls transfected with an empty vector and normalised against Renilla luciferase activity as described in Materials and Methods. Data shown are the mean \pm s.e.m. of four independent experiments. (B) Bar graph illustrating the effect of I nM Doc or I 0 nM DEX, singly or in combination, upon AP- Idriven transcriptional activity in PC3 cells transfected with a PGL3-AP- I -LUC plasmid measured $24 \mathrm{~h}$ post-administration of the drugs. This is compared with time-matched controls transfected with an empty vector and normalised against Renilla luciferase activity as described in Materials and Methods. Data shown are the mean \pm s.e.m. of four independent experiments. (C) Bar graph illustrating the relative mRNA transcript levels for the proangiogenic factors IL-8 and CXCLI in PC3 cells $24 \mathrm{~h}$ post-treatment with I nM Doc or $10 \mathrm{nM}$ DEX, administered singly or in combination. Transcript levels were determined using the established QPCR protocols. Values shown represent the mean \pm s.e.m. value of four independent experiments. (D) Bar graph illustrating the levels of CXC-chemokine secretion from PC3 cells $24 \mathrm{~h}$ post-treatment with I nM Doc or $10 \mathrm{nM}$ DEX, administered singly or in combination and calculated from three independent experiments. (E and $\mathbf{F})$ As in (B and $\mathbf{D})$, respectively, except that experiments were conducted in hBMECs. Statistically significant differences in activity, transcript levels or secretion were determined using a two-tailed Student's t-test analysis. $* P<0.05$; $* * P<0.0$ I; $* * * P<0.001$.

Experiments were conducted as previously described for the tumour cells. As observed before, addition of DEX to these endothelial cells reduced IL-8 transcript levels to $75 \%$ of that observed in untreated, time-matched control cells. Administration of docetaxel ( $1 \mathrm{nM})$ was shown to increase IL- 8 mRNA transcript levels to the levels approaching double that of control levels, whereas co-treatment with DEX reduced IL-8 transcript levels to $73 \%$ of that observed in untreated, time-matched control cells $(P<0.05)$ (Figure 2E). Similarly, DEX was shown to reverse docetaxel-induced CXCL1 mRNA transcript levels in these endothelial cells $(P<0.05)$ (Figure 2E). Furthermore, using ELISAs, we were able to confirm that co-administration of DEX attenuated the docetaxel-induced increase in IL-8 and CXCL1 secretion from hBMECs $(P<0.05$ in either case) (Figure $2 \mathrm{~F})$.

\section{Effect of DEX administration upon docetaxel cytotoxicity in CRPC and endothelial cells}

Nuclear factor $-\kappa \mathrm{B}$ and AP-1 transcription are each associated with promotion of cell survival and cell proliferation. We therefore examined the cytotoxicity of docetaxel $(0.01 \mathrm{nM}$ to $100 \mu \mathrm{M})$ in PC3 cells for $72 \mathrm{~h}$, when administered alone or in combination with 
PC3 cells

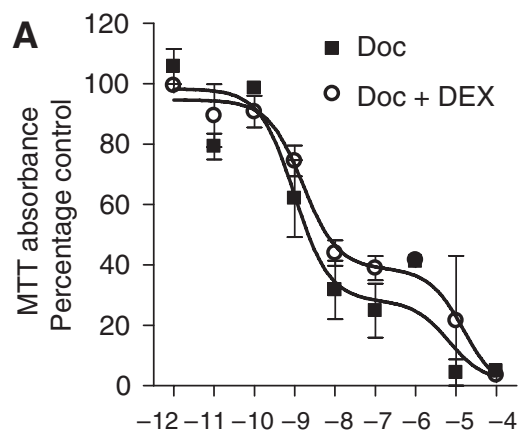

(Docetaxel), $\mathrm{M}$

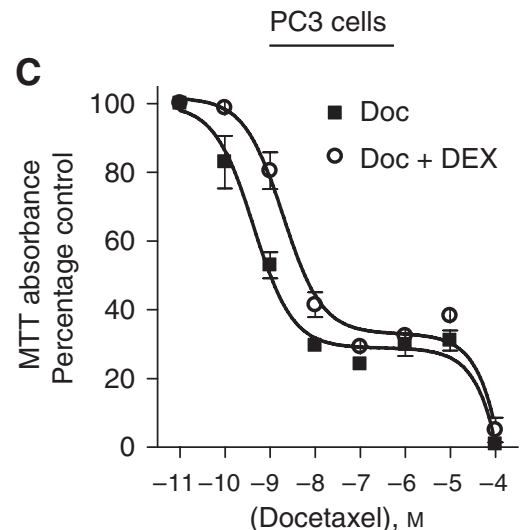

LNCaP cells

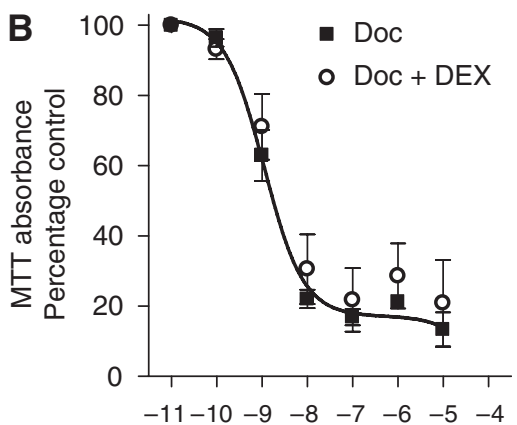

(Docetaxel), $\mathrm{M}$

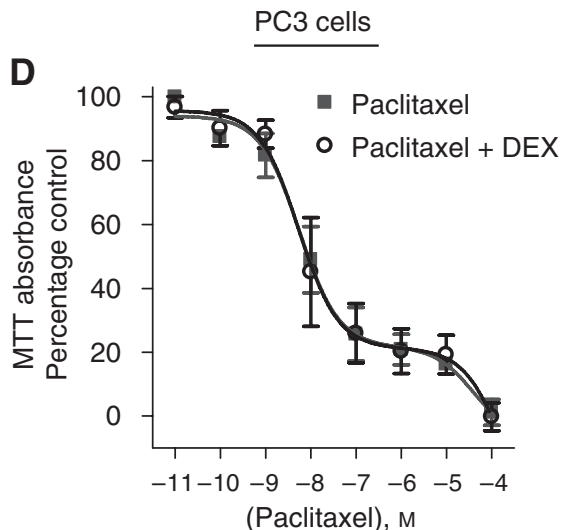

Figure 3 Effect of dexamethasone (DEX) upon the cytotoxicity of taxanes to CaP cells. Graphs showing the effect of docetaxel, in the absence and presence of 10 nM DEX, upon the viability of $(\mathbf{A})$ PC3 and (B) LNCaP cells. Data points shown on the graphs represent the mean \pm s.e.m. value calculated from four and three experiments, respectively. (C) Graph showing the effect of docetaxel, following pre-treatment (48 h) of PC3 cells with I0 nM DEX. The data points shown represent the mean \pm s.e.m. of three independent experiments. (D) Graph showing the effect of paclitaxel in the absence and presence of IO nM DEX upon the viability of PC3 cells. The data points shown represent the mean \pm s.e.m. of three independent experiments. In all scenarios, DEX failed to enhance the cytotoxicity of taxanes on CaP cells.

DEX (10 nM). An MTT assay was performed to assess cell viability. Concentration-response curves, modelling to a two-site competition equation were generated, suggesting two different modes of action of docetaxel activity in PC3 cells. A concentrationdependent decrease in cell viability was observed following treatment with docetaxel with a calculated $\mathrm{IC}_{50}$ value of $2.17 \mathrm{~nm}$. However, concurrent administration of DEX (10 nM) failed to enhance the cytotoxicity of docetaxel ( $\mathrm{IC}_{50} 3.31 \mathrm{nM}$ ) or indeed, alter the distribution of viable cells across the two-distinct populations (Figure 3A). Similarly, concurrent administration of DEX did not influence the cytotoxicity of docetaxel in hBMECs (data not shown).

Clinically, DEX is given to patients in the $24 \mathrm{~h}$ before docetaxel. As concurrent treatment of DEX ( $10 \mathrm{nM})$ failed to alter the potency of docetaxel, we conducted a further series of experiments examining the effect of pre-treating PC3 cells with DEX before docetaxel administration. The PC3 cells were treated with DEX $(10 \mathrm{nM})$ for $48 \mathrm{~h}$, followed by treatment with docetaxel over a concentration range of $0.01 \mathrm{~nm}$ to $100 \mu \mathrm{m}$ for $72 \mathrm{~h}$. Control samples were not pre-treated with DEX. Cell viability was assessed by performing MTT assays. However, pre-treatment with DEX was observed to decrease the cytotoxicity of docetaxel by a factor of five-fold ( $\left.\mathrm{IC}_{50} 5.94 \mathrm{nM}\right)$, as compared to control (1.2 nM). Therefore, scheduling has no apparent effect on the ability of DEX to increase docetaxel cytotoxicity in CRPC cells (Figure 3C). Experiments were also conducted using another taxane, paclitaxel.
Co-administration of DEX similarly failed to increase the potency of paclitaxel in PC3 cells (Figure 3D).

\section{Suppression of NF- $\kappa$ B activation or extracellular IL-8 levels does not enhance docetaxel-induced cytotoxicity in PC3 cells}

To determine whether a more potent and direct inhibition of NF$\kappa \mathrm{B}$ activity may potentiate the cytotoxicity of docetaxel, PC3 cells were treated with docetaxel in the absence and presence of the NF$\kappa \mathrm{B}$ inhibitor, BAY11-7082, administered at a final concentration of $5 \mu \mathrm{M}$. However, BAY11-7082 failed to potentiate the cytotoxicity of docetaxel upon PC3 cells (Figure 4A). We also determined whether the potentiation of IL-8 signalling in response to docetaxel may assist in enabling PC3 cells to withstand taxane therapy. Interleukin-8 signalling was initially inhibited using a neutralising anti-IL-8 monoclonal antibody, administered at a concentration of $4 \mu \mathrm{g} \mathrm{ml}^{-1}$. However, no potentiation of docetaxel sensitivity was observed following the inhibition of extracellular IL-8 levels in the PC3 cell media (Figure 4B). In a further series of experiments, we used the CXCR2 antagonist AZ10397767 at a concentration of $20 \mathrm{nM}$ to attenuate any potential signalling effect resulting from the activity of additional, closely related CXC-chemokines to IL-8 (e.g., CXCL1). However, co-administration of AZ10397767 also had no effect on the cytotoxicity of docetaxel (Figure 4C) or paclitaxel (Figure 4D) in the PC3 cells. Therefore, direct (BAY11-7082) or 

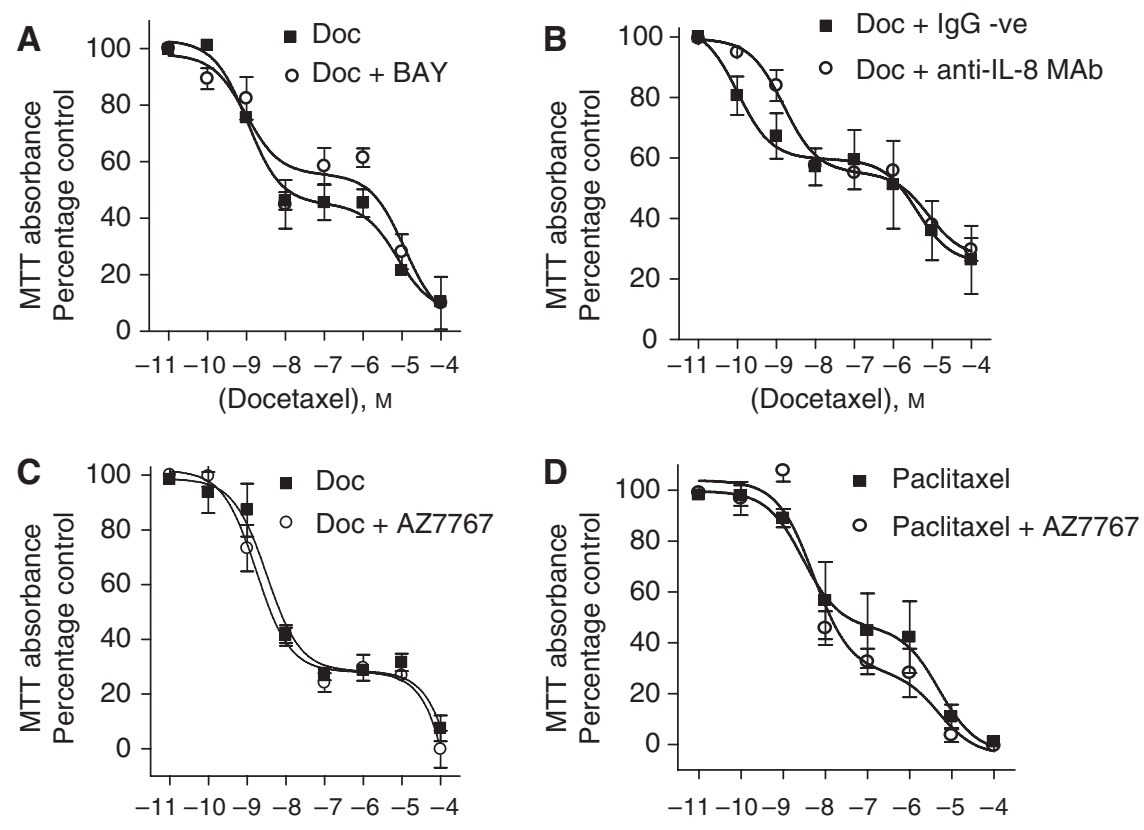

(Docetaxel), $\mathrm{M}$

(Paclitaxel), $\mathrm{M}$

Figure 4 Effect of inhibiting NF- $\kappa \mathrm{B}$, IL-8 or CXC-chemokine expression upon taxane cytotoxicity to PC3 cells. Graphs presenting the effect of coadministering (A) $5 \mu \mathrm{M}$ BAY- I I-7082, (B) $4 \mu \mathrm{g} \mathrm{ml}{ }^{-1}$ anti-IL-8 monoclonal Ab, or (C) $20 \mathrm{~nm} \mathrm{AZI} 0397767$ upon the cytotoxicity of docetaxel in PC3 cells, (D) Graph presenting the effect of administering increasing concentrations of paclitaxel in the absence and presence of $20 \mathrm{nM}$ AZI0397767 upon the viability of PC3 cells. Data points shown represent the mean \pm s.e.m. of three or four independent experiments. In all scenarios presented in this figure, pharmacological interventions inhibiting the NF- $\kappa$ B pathway or proangiogenic CXC-chemokine signalling failed to enhance the cytotoxicity of taxanes on PC3 cells.

indirect (DEX) perturbation of the NF- $\kappa \mathrm{B}$ transcription factor or two of its downstream signalling effectors (IL-8/CXCR2) does not appear to sensitise PC3 cells to the effects of docetaxel.

\section{DEX potentiates the antiangiogenic activity of docetaxel}

Dexamethasone and docetaxel are independently associated with the promotion of antiangiogenic effects in in vivo models of cancer. Therefore, in the absence of DEX modulating the cytotoxicity of docetaxel to CRPC cells, we investigated whether the capacity of DEX to attenuate the docetaxel-induced expression of proangiogenic factors may enhance the established antiangiogenic activity of taxanes. Initially, we used a commercial AngioKit assay (TCS), which reproduces the different phases of angiogenesis. Docetaxel (1 nM) and/or DEX (10 nM) were added to the AngioKit wells every $72 \mathrm{~h}$ and the assay was conducted for 11 days before staining with CD31 as described in Materials and Methods. Administration of DEX alone had a minimal but not statistically significant effect upon either mean vessel area or mean vessel length (Figure 5B). Docetaxel, in contrast, had a marked effect on vessel development resulting in an almost $90 \%$ reduction in mean vessel area $(P<0.05)$ and an over $70 \%$ reduction in mean vessel length compared with untreated cells $(P<0.05)$ (Figure 5B). Interestingly, co-administration of DEX was observed to potentiate the antiangiogenic activity of docetaxel. The mean vessel area was reduced by a further $50 \%$ in cells treated with DEX and docetaxel compared with the effect of docetaxel alone $(P<0.01)$. Similarly, mean vessel length was also reduced by $50 \%$ following coadministration of DEX with docetaxel $(P<0.05)$ (Figure $5 \mathrm{C})$.

The antiangiogenic effect of DEX and docetaxel was studied further, exploiting a chamber assay in the skin flap of SCID mice to determine the effect of these agents upon the vascularisation of an implanted fragment of a PC3 tumour. The parameters of vessel diameter, branch points and segment length were measured from images taken of the growing tumours at days $9,11,15$ and 18 post- implantation (drug treatments initiated on day 8). Images shown compare the effect of DEX on tumour vasculature against the potent antiangiogenic effect of co-administering DEX with docetaxel over the 10-day period (Figure 6A). A comparison of the effect of vehicle control, DEX, docetaxel and the combined DEX/docetaxel treatment on the organisation of the tumour vasculature at day 10 post-treatment is also shown (Figure 6B).

Images of the tumour vasculature were subjected to further quantitative analysis. Treatment with DEX alone resulted in no significant difference in vessel diameter (Figure 6C), the number of branch points observed (Figure 6D) or the average segment length of the blood vessel (Figure 6E) relative to control over the course of the experiment. In contrast, administration of docetaxel resulted in a marked reduction in the number of small diameter blood vessels that could be observed throughout the tumour mass $7(P=0.018)$ and 10 days $(P=0.011)$ post-treatment relative to control (Figure 6C). This coincided with a decrease in the number of vessel branch points detected (Figure 6D) and an increase in the vessel segment length (Figure $6 \mathrm{E}$ ) measured within the tumours on each of these days.

The combination of DEX with docetaxel enhanced the antiangiogenic response further, potentiating the increase in the average vessel diameter and vessel segment length within the tumour and reducing further the number of vessel branch points detected, relative to the effect of docetaxel alone, 7 and 10 days post-treatment. This was particularly evident in quantifying the number of branch points where statistically significant differences between the DEX/docetaxel and docetaxel treatments were observed at days $7(P<0.001)$ and $10(P<0.05)$. With respect to the other parameters under investigation, the trend towards an increase in the vessel diameter and segment length in the DEX/ docetaxel-treated tumours relative to docetaxel alone approached but did not attain statistical significance in a two-tailed $t$-test in this experimental design (e.g., $P=0.06$ for difference in segment length and diameter at day 10). Furthermore, although again not 
A

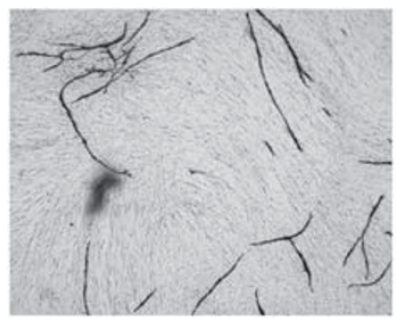

Control

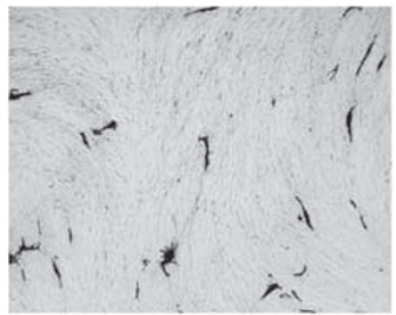

Docetaxel

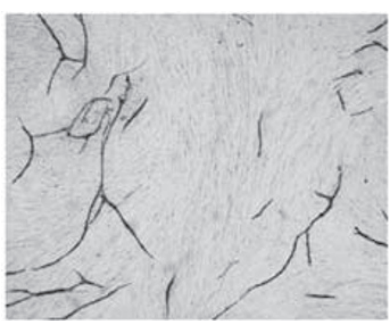

Dexamethasone

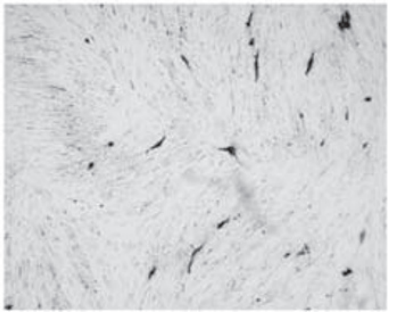

Docetaxel + dexamethasone
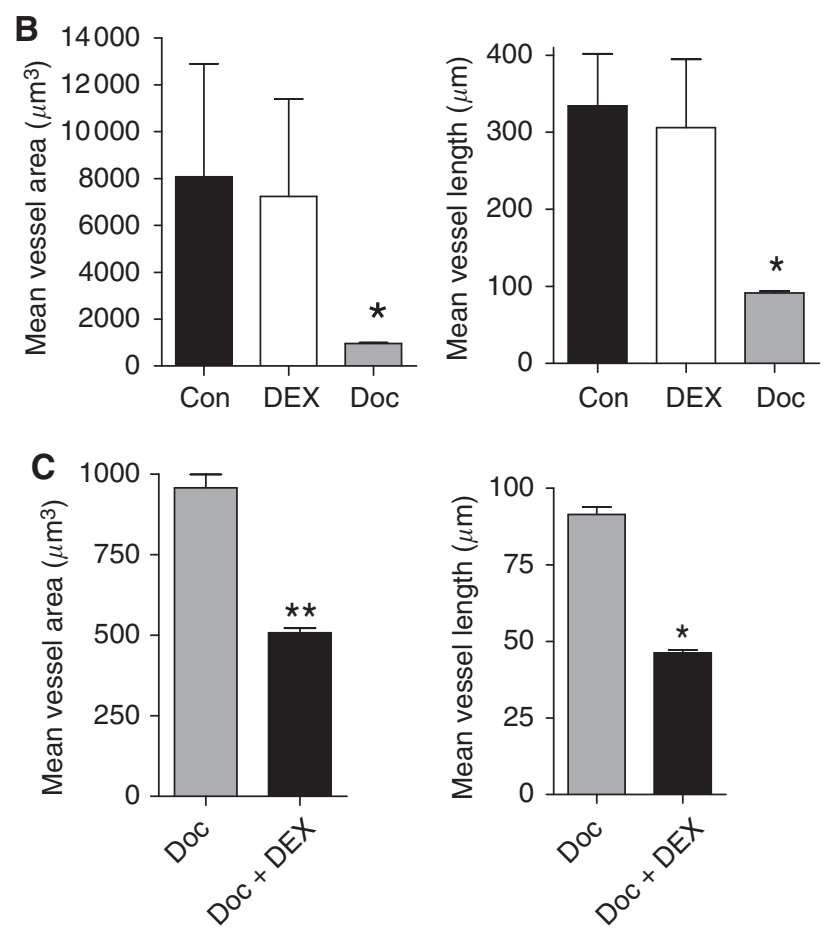

Figure 5 Enhancement of the antiangiogenic effect of docetaxel by combination with dexamethasone (DEX) in endothelial tube formation assays. (A) Representative field images of endothelial tube formation following administration of a vehicle control (top left quadrant), I 0 nM DEX (top right quadrant), I nM docetaxel (Doc) (lower right quadrant) and I nM docetaxel co-administered with $10 \mathrm{nM}$ DEX (lower right quadrant). All images shown are at a magnification of $\times 10$. (B) Quantitation of mean vessel area $\left(\mu \mathrm{m}^{3}\right)$ (left panel) and mean vessel length $(\mu \mathrm{M})$ (right panel) as determined from analysis of 10 representative fields in vehicle control-, $10 \mathrm{~nm}$ DEX- or I nM Doc-treated endothelial cells. Columns represent the mean \pm s.e.m. value. $(\mathbf{C})$ Comparison of the mean vessel area $\left(\mu \mathrm{m}^{3}\right)$ (left panel) and mean vessel length $(\mu \mathrm{M})$ (right panel) as determined by image analysis of I 0 representative fields in wells receiving I nM Doc-treated vs I nM Doc plus 10 nm DEX. Columns represent the mean \pm s.e.m. value. Statistically significant differences in vessel area and length in (B) and (C) were determined using a two-tailed Student's $t$-test analysis. ${ }^{*} P<0.05$; ${ }^{*} P P<0.0$ l.

statistically significant, our results suggest that the combination of DEX with docetaxel increases the rate of onset of the observed antivascular effect in the tumours, supported by the detection of an

increased average vessel diameter and average segment length within 3 days of treatment.

\section{DISCUSSION}

Docetaxel is at present the chemotherapy agent of choice in the treatment of metastatic CRPC. To offset the risk of developing docetaxel-induced hypersensitivity, patients treated with docetaxel also received DEX pre-medication (Tannock et al, 2004). As DEX administration alone has been reported to have clinical benefit in CRPC patients (Venkitaraman et al, 2008), this has led to speculation that DEX may contribute in part to the increased survival benefit of patients receiving docetaxel. The objective of our study was to characterise a mechanism that may explain a synergy by which DEX may potentiate the clinical benefit of docetaxel in patients with CRPC.

Experiments were conducted primarily on the representative CRPC cell line PC3 (originally derived from a bony metastasis of human prostate carcinoma) with key experiments repeated in a transformed bone marrow endothelial cell line, as outgrowth of secondary lesions within the bone is the predominant complication associated with CRPC. Consistent with its anti-inflammatory action, we observed that DEX administration decreased the constitutive NF- $\kappa$ B transcriptional activity in the PC3 cells. Consequently, we were able to show a decreased transcription and/or secretion of the CXC-chemokines IL-8 and CXCL1 and the proangiogenic growth factor, VEGF. This response was also observed in hBMECs, where DEX treatment resulted in the suppression of IL-8 and CXCL1 gene transcription and/or secretion.

Constitutive activity of NF- $\kappa \mathrm{B}$ has been reported in $\mathrm{CaP}$ cell lines and/or biopsy tissue and is associated with regulating the expression of genes that induce cell proliferation and/or underpin cell survival (Huang et al, 2001; Fradet et al, 2004; Ross et al, 2004; Shukla et al, 2004; Sweeney et al, 2004; Domingo-Domenech et al, 2005). However, despite suppressing the constitutive activity of the NF- $\kappa \mathrm{B}$ transcription factor, DEX administration failed to reduce the proliferation or the viability of PC3 tumour cells or hBMECs. In addition, we observed that co- or pre-administration of DEX failed to potentiate the cytotoxicity of docetaxel in PC3 cells. Interestingly, our findings support several previous observations that report the absence of a cytotoxic or antiproliferative effect of DEX in CaP cells. For example, DEX has been reported to antagonise rather than enhance the potency of conventional cytotoxic chemotherapy agents, including doxorubicin, cisplatin or etoposide, in PC3 cells (Carollo et al, 1998). Indeed, DEX has been shown to induce resistance to several cytotoxic agents, including the taxane, paclitaxel, in cells isolated from surgical resections of prostate tumours (Zhang et al, 2006) and to a range of cytotoxics in xenograft models of $\mathrm{CaP}$ (Zhang et al, 2007). Studies in macrophages, endothelial, airway smooth muscle and cancer cells have shown that DEX-induced glucocorticoid receptor signalling increases the expression of MAPK phosphatase-1, resulting in decreased MAPK signalling in these cells and contributing to the anti-inflammatory effect (Wu et al, 2005; Abraham et al, 2006; Furst et al, 2007; Issa et al, 2007). Interestingly, overexpression of MAPK phosphatase-1 has been shown to attenuate taxaneinduced, proapoptotic JNK signalling in breast cancer cells $(\mathrm{Wu}$ et al, 2005). Therefore, this suggests a possible mechanism to explain why DEX fails to enhance the sensitivity of $\mathrm{CaP}$ or endothelial cells to docetaxel-induced cytotoxicity.

Taxane administration has previously been reported to induce the expression of the proangiogenic CXC chemokine IL- 8 in a range of cancer cell lines (Collins et al, 2000; Uslu et al, 2005). We too have observed this effect in PC3 cells and hBMECs. Docetaxel administration potentiated the transcriptional activity of AP-1 and $\mathrm{NF}-\kappa \mathrm{B}$ in PC3 cells and hBMECs, resulting in increased synthesis 

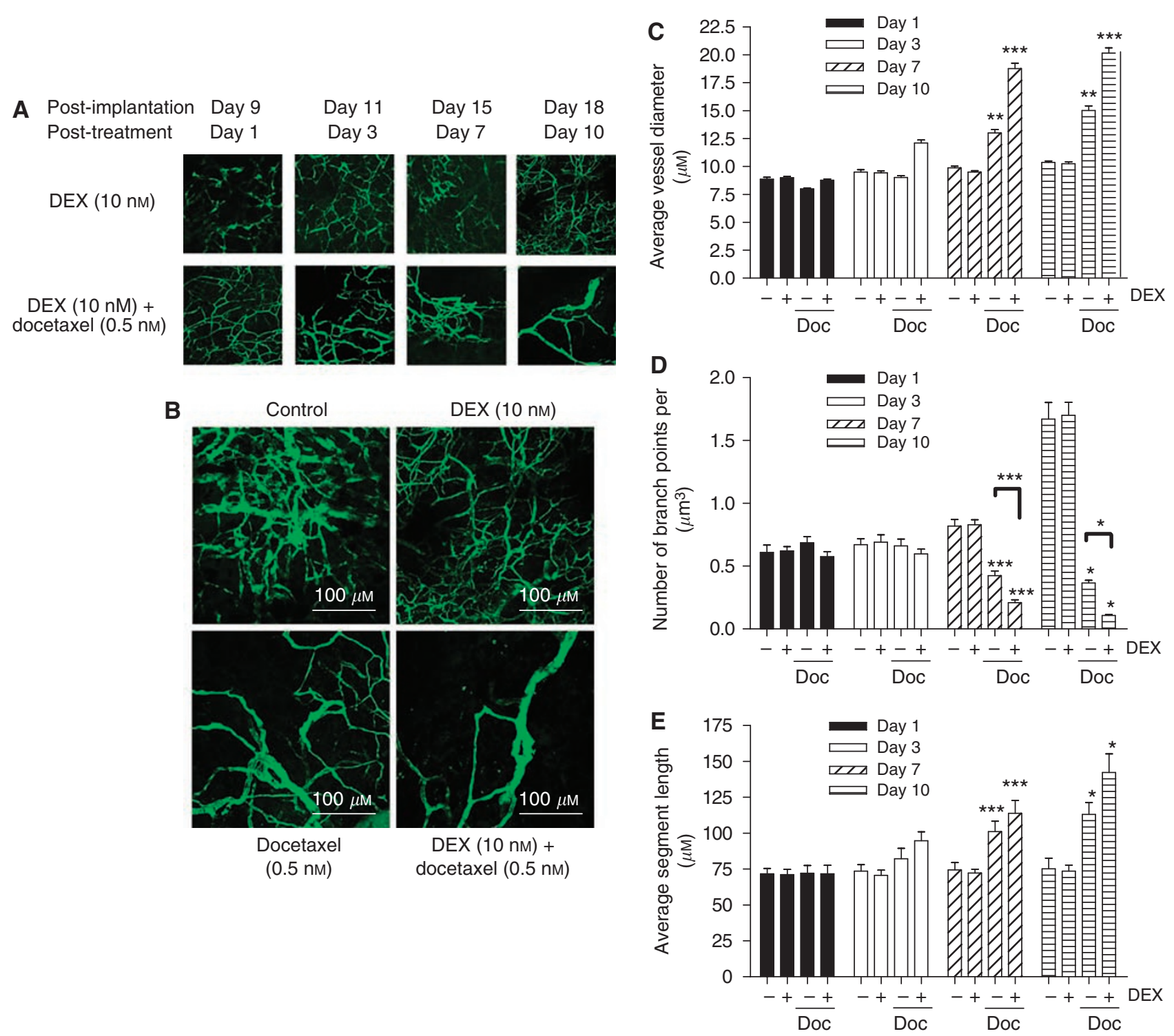

Figure 6 Enhancement of the antiangiogenic effect of docetaxel by combination with dexamethasone (DEX) in a dorsal skin flap assay. PC3 tumour fragments were implanted in a subcutaneous 'window chamber' apparatus on the backs of SCID mice. The development of intratumoural blood vessels was imaged over a 10-day period following treatment with DEX or docetaxel (Doc). The vasculature was visualised using a multiphoton confocal microscope following a tail vein injection of $50 \mu \mathrm{l}$ of $150 \mathrm{kDa}$ FITC-labeled dextran $\left(50 \mathrm{mg} \mathrm{ml}^{-1}\right)$. (A) Representative images showing the response of blood vessel in PC3 tumours receiving 10 nM DEX (top panel) or combined treatment with 10 nM DEX plus 0.5 nM Doc. Images clearly depict a reduction in blood vessels in tumours receiving Doc. (B) Representative images showing the comparison of the vasculature within PC3 tumours I0-day post-initiation of treatment administration. Images shown are for vehicle control (top left quadrant), $10 \mathrm{nM}$ DEX (top right quadrant), $0.5 \mathrm{nM}$ Doc (lower left quadrant) and the combined treatment of $10 \mathrm{~nm}$ DEX plus $0.5 \mathrm{~nm}$ Doc (lower right quadrant). The loss of small vessels is again evident in the Doc-treated tumours with further selection for large diameter vessels in those tumours receiving the combined DEX/Doc treatment. (C) Quantitative analysis of vessel diameter in vehicle control-, I 0 nM DEX-, 0.5 nM Doc and $10 \mathrm{nM}$ DEX/0.5 nM Doc-treated PC3 tumours at four different times post-initiation of treatment. Bars shown represent the mean \pm s.e.m. value calculated from the analysis of 10 independent fields in each of five mice. (D) As in (C) except that bars represent the mean \pm s.e.m. number of vessel branch points determined in the tumours. (E) As in $(\mathbf{C})$ except that bars represent the mean \pm s.e.m. value calculated for vessel segment length determined in the tumours. Statistically significant differences in vessel diameter, number of branch points or vessel segment length were determined using a one-way ANOVA. * $P<0.05$; ** $P<0.01$; *** $P<0.001$.

and secretion of IL-8 and a related CXC-chemokine CXCL1. However, co-administration of DEX was observed to attenuate the docetaxel-induced AP-1 and NF- $\kappa \mathrm{B}$ transcriptional activity and abrogated docetaxel-induced CXC-chemokine gene transcription and secretion in PC3 cells and endothelial cells. We have recently reported that the induction of IL-8 signalling in hypoxic and normoxic $\mathrm{CaP}$ cell lines activates cell survival signalling and confers a survival advantage to these cells in response to DNAdamage agents (Maxwell et al, 2007; Wilson et al, 2008b), antiandrogens (Seaton et al, 2008) and biological inducers of apoptosis such as TNF-receptor apoptosis-inducing ligand (Wilson et al, 2008a). Direct inhibition of NF- $\kappa$ B using BAY11-7082 or direct antagonism of IL-8 signalling, targeting the ligand with a neutralising antibody or through a CXCR2-receptor antagonist, failed to potentiate the cytotoxicity of docetaxel in these cells. It has been previously reported that overexpression of IL-8 in ovarian cancer cells had no appreciable effect on paclitaxel resistance in vitro (Duan et al, 2002). However, recent in vivo studies using liposome-encapsulated siRNA oligonucleotides to target IL-8 expression has shown that targeting this chemokine 
reduces microvessel density and significantly enhances the antiproliferative effect of docetaxel on HeyA8 and SKOV3ip1 ovarian tumour growth (Merritt et al, 2008).

Dexamethasone has been shown to suppress proangiogenic gene transcription and secretion in a range of CRPC cells in vitro, whereas a subcutaneous administration of DEX inhibits tumour growth and angiogenesis in an in vivo DU145 xenograft model of CRPC (Yano et al, 2006). The impact of co-administering DEX on the antiangiogenic activity of docetaxel was initially studied using an in vitro assay that measures the capacity of endothelial cells to promote vessel development in a co-culture system. Dexamethasone had a minimal but not statistically significant effect in reducing the development of CD31 + vessels. However, addition of DEX did potentiate the pronounced antiangiogenic activity of docetaxel, reducing both the observed mean vessel length and mean vessel area. This result was further confirmed through realtime imaging of the vasculature in an implanted PC3 tumour in an SCID mouse, showing a significant loss of intratumoural vascular development in tumours that were concurrently treated with DEX and docetaxel. A pronounced decrease in vessel branching and a reduction in the number of small developing vessels within the tumour was clearly visible within the tumour, consistent with the reduced capacity of the tumour to stimulate de novo vessel development. Therefore, the ability of DEX to suppress IL-8, CXCL1 and VEGF would appear to underpin an enhanced suppression of the tumour vasculature in the PC3 model of CRPC and potentiate the antiangiogenic effect of docetaxel. Consequently, using either DEX to inhibit IL-8 gene expression in CRPC cells or the IL-8 gene-silencing strategy in ovarian cancer cells (Merritt et al, 2008) indicates that IL-8 signalling does not modulate the mechanistic basis of taxane-induced cell death in tumour cells. Instead, these studies both suggest that suppressing the level of IL-8 signalling capacity within the microenvironment of the tumour clearly enhances the therapeutic benefit of taxanes, mediated through a pronounced suppression of angiogenesis within the tumour. Although these studies have not delineated the mechanism underpinning the reduced vascularisation observed in the DEX/docetaxel-treated tumours, the apparent absence of an effect in regulating endothelial cell survival suggests that the decrease in CXC-chemokine signalling potential within the tumour may attenuate the capacity of endothelial cells to migrate and/or promote tube formation. Understanding the mechanism of action will be the subject of future experiments in our laboratory.

In conclusion, we have shown that DEX attenuates docetaxelinduced $\mathrm{AP}-1$ and NF- $\kappa \mathrm{B}$ activation, reducing the synthesis of proangiogenic factors in both $\mathrm{CaP}$ and endothelial cells, with an ultimate effect of reducing de novo vessel development in a prostate tumour. Our data indicate that DEX potentiates the antiangiogenic as opposed to the cytotoxic activity of docetaxel on tumour cells. Angiogenesis is critical in accelerating primary tumour growth and in establishing colonisation at secondary sites and therefore, may explain why a combination of these two agents extends the median survival of patients with advanced $\mathrm{CaP}$. Consequently, many of the novel antiangiogenic agents undergoing clinical trials may find significant utility and purpose in treating CRPC, especially in combination with existing agents such as docetaxel.

\section{ACKNOWLEDGEMENTS}

This work was supported by the Prostate Cancer Research Foundation (DJJW and JMO'S) and the Northern Ireland HPSS R\&D Office (EAT/2546/03 (PS, RHW and DJJW)). We gratefully acknowledge Drs Simon T Barry and David Blakey of AstraZeneca (Alderley Park, Cheshire) for provision of AZ10397767. We extend our thanks to Stephen McNiece and the Oncology and Haematology Pharmacy of Belfast City Hospital for consultation and for provision of the chemotherapy drugs used in this study.

\section{REFERENCES}

Abraham SM, Lawrence T, Kleiman A, Warden P, Medghalchi M, Tuckermann J, Saklatvala J, Clark AR (2006) Antiinflammatory effects of dexamethasone are partly dependent on induction of dual specificity phosphatase-1. J Exp Med 203: 1883 - 1889, doi:10.1084/jem.20060336

Akakura K, Suzuki H, Ueda T, Komiya A, Ichikawa T, Igarashi T, Ito H (2003) Possible mechanism of dexamethasone therapy for prostate cancer: suppression of circulating level of interleukin-6. Prostate 56: $106-109$

Araki S, Omori Y, Lyn D, Singh RK, Meinbach DM, Sandman Y, Lokeshwar VB, Lokeshwar BL (2007) Interleukin-8 is a molecular determinant of androgen independence and progression in prostate cancer. Cancer Res 67: $6854-6862$, doi: 10.1158/0008-5472

Carollo M, Parente L, D'Alessandro N (1998) Dexamethasone-induced cytotoxic activity and drug resistance effects in androgen-independent prostate tumour PC3 cells are mediated by lipocortin 1. Oncol Res 10: $245-254$

Caruso DJ, Carmack AJ, Lokeshwar VB, Duncan RC, Soloway MS, Lokeshwar BL (2008) Osteopontin and interleukin-8 expression is independently associated with prostate cancer recurrence. Clin Cancer Res 14: $4111-4118$, doi: 10.1158/1078-0432

Collins TS, Lee LF, Ting JP (2000) Paclitaxel up-regulates interleukin-8 synthesis in human lung carcinoma through an NF-kappaB- and AP-1dependent mechanism. Cancer Immunol Immunother 49: 78-84

De Bosscher K, Vanden Burghe W, Haegeman T (2003) The interplay between the glucocorticoid receptor and nuclear factor-kappaB or activator protein-1: molecular mechanisms for gene repression. Endocr Rev 24: $488-522$

Domingo-Domenech J, Mellado B, Ferrer B, Truan D, Codony-Servat J, Sauleda S, Alcover J, Campo E, Gascon P, Rovira A, Ross JS, Fernández PL, Albanell J (2005) Activation of nuclear factor-kappaB in human prostate carcinogenesis and association to biochemical relapse. $\mathrm{Br} J$ Cancer 93: $1285-1294$, doi:10.1038/sj.bjc.6602851

Duan Z, Lamendola DE, Penson RT, Kronish KM, Seiden MV (2002) Overexpression of IL-6 but not IL-8 increases paclitaxel resistance of U-2OS human osteosarcoma cells. Cytokine 17: 234-242, doi:10.1006/ cyto.2001.1008

Fradet V, Lessard L, Begin LR, Karakiewicz P, Masson AM, Saad F (2004) Nuclear factor-kappaB nuclear localization is predictive of biochemical recurrence in patients with positive margin prostate cancer. Clin Cancer Res 10: $8460-8464$

Furst R, Schroeder T, Eilken HM, Bubik MF, Kiemer AK, Zahler S, Vollmar AM (2007) MAPK phosphatase-1 represents a novel anti-inflammatory target of glucocorticoids in the human endothelium. FASEB J 21: 74-80, doi: $10.1096 /$ fj.06-6752com

Huang J, Yao JL, Zhang L, Bourne PA, Quinn AM, di Sant'Agnese PA, Reeder JA (2005) Differential expression of interleukin-8 and its receptors in the neuroendocrine and non-neuroendocrine compartments of prostate cancer. Am J Pathol 166: 1807-1815

Huang S, Pettaway CA, Uehara H, Bucana CD, Fidler IJ (2001) Blockade of NF-kappaB activity in human prostate cancer cells is associated with suppression of angiogenesis, invasion, and metastasis. Oncogene 20: $4188-4197$

Inoue K, Slaton JW, Eve BY, Kim SJ, Perrotte P, Balbay MD, Yano S, Bar-Eli M, Radinsky R, Pettaway CA, Dinney CP (2000) Interleukin 8 expression regulates tumourigenicity and metastases in androgen-independent prostate cancer. Clin Cancer Res 6: 2104-2119

Issa R, Xie S, Khorasani N, Sukkar M, Adcock IM, Lee KY, Chung KF (2007) Corticosteroid inhibition of growth related oncogene protein alpha via mitogen-activated kinase phosphatase-1 in airway smooth muscle cells. J Immunol 178: $7366-7375$ 
Kim SJ, Uehara H, Karashima T, McCarty M, Shih N, Fidler IJ (2001) Expression of interleukin-8 correlates with angiogenesis, tumourigenicity, and metastasis of human prostate cancer cells implanted orthotopically in nude mice. Neoplasia 3: 33-42

Maxwell PJ, Gallagher R, Seaton A, Wilson C, Scullin P, Pettigrew J, Stratford IJ, Williams KJ, Johnston PG, Waugh DJ (2007) HIF-1 and $\mathrm{NF}-\kappa \mathrm{B}$-mediated upregulation of CXCR1 and CXCR2 expression promotes cell survival in hypoxic prostate cancer cells. Oncogene 26: 7333-7345, doi:10.1038/sj.onc.1210536

McCarron SL, Edwards S, Evans PR, Gibbs R, Dearnaley DP, Dowe A, Southgate C, Easton DF, Eeles RA, Howell WM (2002) Influence of cytokine gene polymorphisms on the development of prostate cancer. Cancer Res 62: 3369-3372

Merritt WM, Lin YG, Spannuth WA, Fletcher MS, Kamat AA, Han LY, Landen CN, Jennings N, De Geest K, Langley RR, Villares G, Sanguino A, Lutgendorf SK, Lopez-Berestein G, Bar-Eli M, Sood AK (2008) Effect of interleukin-8 gene silencing with liposome-encapsulated small interfering RNA on ovarian cancer cell growth. J Natl Cancer Inst 100: 359-372, doi:10.1093/jnci/djn024

Murphy C, McGurk M, Pettigrew J, Santinelli A, Mazzucchelli R, Johnston PG, Montironi R, Waugh DJ (2005) Nonapical and cytoplasmic expression of interleukin-8, CXCR1, and CXCR2 correlates with cell proliferation and microvessel density in prostate cancer. Clin Cancer Res 11: $4117-4127$

Nishimura K, Nonomura N, Satoh E, Harada Y, Nakayama M, Tokizane T, Fukui T, Ono $\mathrm{Y}$, Inoue $\mathrm{H}$, Shin $\mathrm{M}$, Tsujimoto $\mathrm{Y}$, Takayama $\mathrm{H}$, Aozasa $\mathrm{K}$, Okuyama A (2001) Potential mechanism for the effects of dexamethasone on growth of androgen-independent prostate cancer. J Natl Cancer Inst 93: $1739-1746$

O'Rourke M, Ward C, Worthington J, McKenna J, Valentine A, Robson T, Hirst D, McKeown SR (2008) Evaluation of the antiangiogenic potential of AQ4N. Clin Cancer Res 14: 1502 -1509, doi: 10.1158/1078-0432

Petrylak DP, Tangen CM, Hussain MH, Lara Jr PN, Jones JA, Taplin ME, Burch PA, Berry D, Moinpour C, Kohli M, Benson MC, Small EJ, Raghavan D, Crawford ED (2004) Docetaxel and estramustine compared with mitoxantrone and prednisone for advanced refractory prostate cancer. $N$ Engl J Med 351: $1513-1520$

Ross JS, Kallakury BV, Sheehan CE, Fisher HA, Kaufman RP, Kaur P, Gray K, Stringer B (2004) Expression of nuclear factor-kappa B and I kappa B alpha proteins in prostatic adenocarcinomas: correlation of nuclear factor-kappa B immunoreactivity with disease recurrence. Clin Cancer Res 10: $2466-2472$

Seaton A, Scullin P, Maxwell PJ, Wilson C, Pettigrew J, Gallagher R, O'Sullivan JM, Johnston PG, Waugh DJ (2008) Interleukin-8 signaling promotes androgen-independent proliferation of prostate cancer cells via induction of androgen receptor expression and activation. Carcinogenesis 29: $1148-1156$, doi:10.1093/carcin/bgn109

Shukla S, MacLennan GT, Fu P, Patel J, Marengo SR, Resnick MI, Gupta S (2004) Nuclear factor-kappaB/p65 (Rel A) is constitutively activated in human prostate adenocarcinoma and correlates with disease progression. Neoplasia 6: $390-400$

Sweeney C, Li L, Shanmugam R, Bhat-Nakshatri P, Jayaprakasan V, Baldridge LA, Gardner T, Smith M, Nakshatri H, Cheng L (2004) Nuclear factor-kappaB is constitutively activated in prostate cancer in vitro and is overexpressed in prostatic intraepithelial neoplasia and adenocarcinoma of the prostate. Clin Cancer Res 10: 5501-5507

Tannock IF, de Wit R, Berry WR, Horti J, Pluzanska A, Chi KN, Oudard S, Théodore C, James ND, Turesson I, Rosenthal MA, Eisenberger MA, TAX 327 Investigators (2004) Docetaxel plus prednisone or mitoxantrone plus prednisone for advanced prostate cancer. N Engl J Med 351: 1502-1512 Uehara H, Troncoso P, Johnston D, Bucana CD, Dinney C, Dong Z, Fidler IJ, Pettaway CA (2005) Expression of interleukin-8 gene in radical prostatectomy specimens is associated with advanced pathologic stage. Prostate 64: 40 - 49

Uslu R, Sanli UA, Dikmen Y, Karabulut B, Ozsaran A, Sezgin C, Muezzinoglu GG, Omay SB, Goker E (2005) Predictive value of serum interleukin-8 levels in ovarian cancer patients treated with paclitaxelcontaining regimens. Int J Gynecol Cancer 15: 240-245

Veltri RW, Miller MC, Zhao G, Ng A, Marley GM, Wright Jr GL, Vessella RL, Ralph D (1999) Interleukin-8 serum levels in patients with benign prostatic hyperplasia and prostate cancer. Urology 53: 139-147

Venkitaraman R, Thomas K, Huddart RA, Horwich A, Dearnaley DP, Parker CC (2008) Efficacy of low dose dexamethasone in castrationresistant prostate cancer. BJU Int 101: $440-443$

Walters IA, Austin C, Austin R, Bonnert R, Cage P, Christie M, Ebden M, Gardiner S, Grahames C, Hill S, Hunt F, Jewell R, Lewis S, Martin I, Nicholls D, Robinson D (2008) Structure-activity relationships of a series of thiazolopyrimidine-based CXCR2 antagonists. Bioorg Med Chem Lett 18: $798-803$

Waugh DJ, Wilson C, Seaton A, Maxwell PJ (2008) Multi-faceted roles for CXC-chemokines in prostate cancer progression. Front Biosci 13: 4595 - 4604, doi.org/10.2741/3025

Wilson C, Wilson T, Johnston PG, Longley DB, Waugh DJ (2008a) Interleukin- 8 signaling attenuates TRAIL and chemotherapy-induced apoptosis through transcriptional regulation of c-FLIP in prostate cancer cells. Mol Cancer Ther 7: 2649-2661, doi: 10.1158/1535-7163

Wilson C, Purcell C, Seaton A, Oladipo O, Maxwell PJ, O'Sullivan JM, Wilson RH, Johnston PG, Waugh DJJ (2008b) Chemotherapy-induced CXC-chemokine/CXCR2 signaling in metastatic prostate cancer cells confers resistance to oxaliplatin through potentiation of NF- $\kappa \mathrm{B}$ transcription and evasion of apoptosis. J Pharmacol Exp Ther 327: 746-759

Wu W, Pew T, Zou M, Pang D, Conzen SD (2005) Glucocorticoid receptorinduced MAPK phosphatase-1 (MPK-1) expression inhibits paclitaxelassociated MAPK activation and contributes to breast cancer cell survival. J Biol Chem 280: 4117-4124

Yano A, Fujii Y, Iwai A, Kageyama Y, Kihara K (2006) Glucocorticoids suppress tumour angiogenesis and in vivo growth of prostate cancer cells. Clin Cancer Res 12: $3003-3009$

Zhang C, Mattern J, Haferkamp A, Pfitzenmaier J, Hohenfellner M, Rittgen W, Edler L, Debatin KM, Groene E, Herr I (2006) Corticosteroid-induced chemotherapy resistance in urological cancers. Cancer Biol Ther 5: 59-64

Zhang C, Wenger T, Mattern J, Ilea S, Frey C, Gutwein P, Altevogt P Bodenmüller W, Gassler N, Schnabel PA, Dienemann H, Marmé A, Hohenfellner M, Haferkamp A, Pfitzenmaier J, Gröne HJ, Kolb A, Büchler P, Büchler M, Friess H, Rittgen W, Edler L, Debatin KM, Krammer PH, Rutz HP, Herr I (2007) Clinical and mechanistic aspects of glucocorticoid-induced chemotherapy resistance in the majority of solid tumours. Cancer Biol Ther 6: 278-287 